\title{
Social Media Marketing On Brand Equity Of L'sima Tourism, Intermediating Role : Electronic Word Of Mouth
}

Mickhael Kurnianto ${ }^{1 *}$,

Titis Shinta Dhewi ${ }^{2}$

1,2, Department of Management, Faculty of Economics and Business, Universitas Negeri Malang, Indonesia

\section{ARTICLE INFO ABSTRACT}

\section{ISSN: 2723-1097}

\section{Keywords:}

Social Media; Social Media Marketing; Brand Equity; Electronic Word Of Mouth.
Business promotions are directly affected by current technological advancements. Company operators, particularly those in the tourism industry, may conveniently promote their businesses over the internet nowadays. Therefore, the goal of this research is to figure out the direct and indirect effects of Social Media Marketing on Brand Equity through Electronic Word of Mouth. This study employs a quantitative method with a descriptive explanatory approach. The instrument used is a closed questionnaire distributed to L'Sima's line of business, namely Jagongan Jail. The findings of the study reveal that social media marketing has a significant impact on brand equity through electronic word of mouth at L'Sima assimilation and educational facilities. Based on the empirical findings, the author suggests promotion through Youtube, Instagram, and Facebook. While using the platform, L'Sima's may become more well-known as a tourist destination. Promotions will spread rapidly after the advertising program has been running for a while. The value obtained for the social media marketing variable on brand equity through electronic word of mouth is 0.393 , implying that social media promotion has an effect on enhancing the brand equity of L'Sima.

\section{Introduction}

The current technology state has played a significant role in the promotion of the tourism industry. Internet existence helps business owners to promote their business smoother than before. According to a published statistic conducted by Nurhayati (2021) through Statista.com, Indonesia is one of the world's largest online markets, with over 171 million internet users. As of July 2021, the country's online reach was around $70 \%$. Mobile messaging and social media are two popular online activities. YouTube is Indonesia's most popular social media platform, with around 94 percent of the country's online population using it. Mobile internet usage is increasing at double-digit rates, with over 64 percent of the population using it. The census conducted in 2020 BPS is also stated that the population in Indonesia is technologyfriendly, where Indonesian internet users are dominated by Generation $\mathrm{Z}$ as much as $27.94 \%$ and Millennials $25.87 \%$. Both generations were shown to be familiar with social media and keep up with technological developments. Individuals between the ages of 18 and 35 form the majority of social media users.

Journal of Business and Management Review Vol. 3 No. 12022 Page 031- 044

DOI: $10.47153 /$ jbmr31.2712022

*Corresponding Author

Email address: kurniantomichaelfeum@gmail.com 
The rapid growth of technology in the digital world as well as on the internet remains a significant impact on the marketing world. According to (Putri et al., 2016) Indonesians have become increasingly reliant on social media, and businesses are taking advantage of this opportunity to expand their marketing communications and raise their brands through social media, allowing information about enterprises to spread quickly and benefit them. Due to the deployment of COVID-19 in 2020, the global marketing trend has transitioned from traditional (offline) to digital (online). As a result, the social media marketing strategy is projected to be more effective, as it allows potential customers to access a wide range of product information and transact over the internet. Based on this phenomenon, social media features can be used to promote almost anything, including tourism destinations. The provided features make promotions more accessible for business owners. It is easy to use, has a wider reach, and is more cost-effective. That statement seems to be consistent with (Gururaja, 2015) statement, which the leveraging of social media to the tourism products has proved to be a good strategy in improving not only the quality of the business but also the revenues of the tourism industry at large. As a result of these advantages, social media is becoming more appealing as a tool for communicating and advertising. In response to the beneficial function, (Kaur, 2017) emphasized that the tourism industry should advertise through the digital world, underlining the necessity of digital marketing in keeping things relevant to current customers. Ly \& Ly, (2020) also stated that the travel industry can increase the conversion cost if they have a successful value creation strategy and focus on personalizing their services through social media. According to the research, the most critical and various social media resources for travelers are vital, and it can be a potential and crucial sustainable support because of Value, Rareness, Imitability, and Non-substitutable.

Regarding the research conducted as mentioned above, according to necessity, a strong brand equity is undeniably essential to raise an object's brand savviness in order to increase the effectiveness of social media marketing. Yasin and Zahari (2011) reveal that brand equity is the largest source of company assets. The brand is the main thing that is important to the company, thus causing the company's competition to be more competitive in the brand. Companies must know that the brand is very influential on the impact of a company's success in marketing its products. Where to strengthen a brand equity a management needs to build a strategy to be able to compete, to basically the most common factors to be able to build a brand put forward by Kotler and Keller (2009) there are four basic dimensions, namely: brand awareness (brand awareness), perceived quality (perceived quality), brand association (brand association), and brand loyalty (brand loyalty). This is what needs to be developed to create a brand that has benefits and benefits in the modern era as well as a creative and innovative marketing process that can benefit and develop a tourist spot. 
Because A product without a good brand image would be easily forgotten and abandoned by the public. As stated by Tekin, (2016) positive brand image and brand association has a positive effect on the memory and their purchase behavior. The role of brand equity itself is to create value addition on the products and services to make a business survive and be advanced. As stated by Leone et al., (2009), it is critical to understand the state of its product's brand equity. In addition to that view point, cited on (eticon.co.id.), the process of brand improvement is to strengthen the composition of the brand's marketing channels, both directly and indirectly (online and offline). Promotional materials for tourist destinations will reach their intended audience, and a strong and distinct brand will have a favorable impact on the destination's sustainability.

Promotions (social media) and branding are merely two aspects of business optimization. Those who have seen and visited the promoted destination, on the other hand, may recall or spread how the marketing is carried out. Further object optimization demands the spread of communication in cyberspace through the role of E-Word of Mouth (E-WoM). The media is needed as an engagement tool within other customers. As stated by Jalilvand \& Samiei, (2012), E-WoM is defined as a client who understands information about a product that is transmitted to a wide number of people and is accessible via the internet. Electronic word of mouth, according to Jeong et al. (2011) is an informal communication between consumers about particular items that is considered the most essential information on purchases since electronic word of mouth has such a big influence on consumer behavior. Thus, based on the prior remarks, it is hoped that a tourism business will perceive a rise in the number of visitors or profit earned by paying attention to social media marketing, brand equity, and electronic word of mouth.

L'Sima is a tourism destination that functioned as an assimilation and teaching facility. It was designed for the inmates' institution in order to dispel the negative stigma associated with them. Thus, the concept was later made into a public tourist attraction. The presence of L'Sima assimilation and educational facilities is expected to change the negative stigma and introduce that inmates who have served their sentences may develop by the training given in penitentiaries. Quoted from Antaranews.com the Minister of Law and Human Rights dedicated the L'Sima for integration and education facilities. L'Sima had finished the initial stage of development in 2020. During its early stages, L'Sima introduced various tourist attractions to the public, such as a mountain bike trail, picturesque spots for people to snap their visiting memories, cafes, and communal areas (gazebos). Henceforth, this tourist attraction may catalyze inmates' development, encouraging them to become self-sufficient and avoid repeating crimes in the future. With the strengthening of social media marketing on brand equity, it is hoped that later it will be able to bring up many consumers who visit L'Sima tours and 
build E-Wom about the experiences they get coming to L'Sima tourist attractions and will later fix the stigma of bad perceptions to working prisoners.

\section{Literature Review}

\section{Social Media Marketing}

Social media marketing is the practice of promoting brands and content through social media channels to improve brand awareness, traffic, and leads for businesses. As per Santoso, (2020) social media marketing is a method of marketing that uses social web platforms such as blogging, microblogging, social networking to build awareness, recognition, memory, or even engagement for a brand, product, business, individual, or organization, either directly or indirectly. Huang et al (2014) also stated that Social media is a digital platform where users can share and develop social relationships while participating in various online activities. This level of participation allows web users to communicate via instant messages, digital voice, and video sharing. Many businesses utilize social media to expand their marketing initiatives, and companies that share information with their customers can form bonds by sharing their common experiences (Kim et al., 2019). Businesses engagement in social media marketing activities could create brand value for potential customers while also benefiting from consumer feedback (Bui, 2014). Thus, (Gao et al. 2018) Companies these days benefit from social media channels which eliminate geographical barriers. According to Aladwani, (2017) social media marketing indicators comprise (1) Reflective Quality, which would be a person's belief about how well social media content fulfill their needs. (2) Stimulated Quality, i.e. one's feelings about how well social media content matches the needs of their obligations. (3) Quality practice refers to the use of highquality social media content that fits one's needs. (4) Advanced Quality, which refers to one's fervent support for great social media content that fulfills one's needs.

\section{Brand Equity}

Brand awareness is a critical aspect of businesses equity since it has a direct impact on brand equity. If consumer awareness of the brand is weak, it is fair to presume that the brand equity will be low as well. Consumers' capability to recognize or remember a product's brand varies depending on the proportion of brand communication or consumer perception of the brand conveyed. Aaker (1991) proposed a broad definition of brand equity as a set of assets and liabilities linked to a brand, its name, and symbol that add or subtract from the value provided to a firm and/or that firm's customers. (Quoted by Ang, (2000) brand awareness is the ability of consumers to recognize or recall a brand, and customers respond towards products or services based on brand. In accordance to the statements, Keegan et al (1995) on his book refers that Brand equity is also defined as the value endowed to a brand as a 
result of strong relationship that it has built up over time with potential customers and key stakeholders. In general, brand equity reflects the extra value or benefits that a product uses to achieve of its brand name. Thus, Brand equity is described as a valuable intangible asset that has both psychological and financial worth. According to Kim \& Ko, (2012) brand equity indicators can be classified into five categories: (1) brand awareness, (2) brand association, (3) perceived quality, and (4) brand loyalty.

\section{Electronic Word of Mouth}

A positive or negative comment made by a potential or former consumer about a product or company that is intended for the public to notice is known as word of mouth. Electronic Word of Mouth, as per Sindunata, (2018), is a way for people to communicate their impressions about a product or service publicly amongst customers. In conjunction with that, Electronic Word of Mouth, according to Laksana \& Dharmayanti, (2018) is a form of customer expression and an effective tool for impacting customer purchase decisions. Lee \& Koo (2012) also mentioned that E-WOM is defined as customers' positive or negative sharing of varied brands' products on social media via the Internet. In line with all of the statements, Rossmann et al. (2016) stated that Consumer interaction with e-WOM, as per individual and social behavior theories, is related to consumers' prior experiences on these social sites and their recognition by others.

Eka (2016) notes the indicators of electronic word of mouth as follows: (1) platform assistance, i.e. customer trust in the platform used. (2) expressing negative emotions, such as the urge to express consumer dissatisfaction with the product or company (3) care for other customers, i.e. a genuine desire to make suggestions to other consumers. This feedback might take the shape of both favourable and negative product remarks. (4) extraversion/positive self-enhancement, which is the desire of consumers to share their purchase experiences to improve their self-image as smart customers. (5) social advantages, i.e. the desire to share information and communicate with others. (6) Economic incentives, the desire to get rewards from the company. (7) assisting the firm, i.e. customers' willingness to assist the company, this motive develops as a result of consumer satisfaction with the product (8) advice seeking, or the urge to seek advice and suggestions from other customers.

\section{Relationships among three variables (Social Media Marketing, Brand Equity, E- Wom)}

According to the literature mentioned above, various relationships exist among the three dimensions of brand equity, i.e., social media marketing and electronic word of mouth. It is known that the results of previous studies that are in accordance with this research are Godey et al. (2016) with the title "Social media marketing efforts of 
luxury brands: influence on brand equity and consumer behavior" which aims to determine the effect of social media marketing on brand equity in goods. -luxury goods in china. This study led to the results that social media marketing has an effect on brand equity. The second research that connects the variables is Seo et al (2018) social media on brand equity shows that social media trendiness has an important effect on brand awareness and brand image.

H1 : Social Media Marketing has a strong and significant effect on L'Sima's Brand Equity.

H2 : Social Media Marketing has a positive and significant effect on E-WoM L'Sima.

At the next level of the causal relationships among the three dimensions, social media marketing has been shown to affect E-WOM positively. The results of previous studies that are in accordance with supporting research are Yan et al., (2016) with the title "E -WOM from e-commerce websites and social media: Which will consumers adopt" which aims to determine the effect of social media marketing on electronic word of mouth in social commerce. The second study that connects the variables is Afrilinia (2017) with the title "The influence of social media marketing and product knowledge on purchasing decisions and their impact on electronic word of mouth" where the results of this study are the influence of social media marketing has an important effect on electronic word of mouth.

Furthermore, judging from the past literature, E-WoM has a positive and significant effect on Brand Equity. The results of previous studies that are in accordance with supporting research are Asdiana Luh (2020) with the title "The role of brand image mediates E-Wom effects in buying interest in triton learning institutions" where the results of this study are the influence of electronic word of mouth on brand equity. The second study that connects the variables is Bastos et al., (2021) with the title "Making word-of-mouth impactful: Why consumers react more to E-WOM about experiential than material purchases".

H3 : L'Sima's E-WoM has a positive and significant effect on Brand Equity.

H4 : Social Media Marketing has an indirect effect on Brand Equity through L'Sima's E-WoM.

Latter seen from past literature, Social Media Marketing has an indirect effect on Brand Equity through E-WoM. The results of previous studies that are in accordance with supporting research are Eun ju Seo et al. (2020) with the title "The Effect of social media usage characteristics on E-WoM, Trust, and Brand Equity: Focusing on Users of Airlen Social Media". mouth has an important effect. 


\section{Method}

The independent variable in this study is Social Media Marketing (X), the intervening variable is Electronic Word of Mouth $(Z)$, and the dependent variable is Brand Equity $(Y)$. This study's population consists of Malang residents who own social media accounts. Primary inclusion criteria for the participants were individuals who educated others about L'Sima's tourism through their social media account and those who are familiar with L'Sima's tourism. This study uses descriptive and explanatory research with the complete method of data analysis using partial least squares structural equation modeling (warppls) analysis. The sampling technique in this study was using purposive sampling with a sample of 200 respondents. The data collection method in this research is using a questionnaire. The questionnaire was distributed using an online Google form in the L'Sima line of a business object. In this study, the scale used is the Likert scale (1-5).

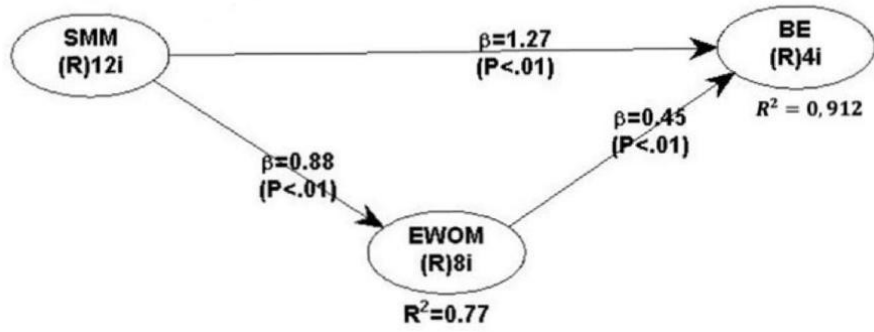

Figure 1: PLS Analysis Model

\section{Inner Model -Adjusted R-Squares}

The adjusted R-Squared value can be used to explain the effect of certain exogenous latent variables on the presence or absence of endogenous latent variables. The summary shown in the following table shows the Adjusted R-Squared calculation results.

Table 1: Adjusted R-Squared

\begin{tabular}{lll}
\hline Endogen Variable & $\begin{array}{l}\text { Adjusted } \\
\text { squared }\end{array}$ & R- \\
\hline Brand Equity & 0,912 \\
\hline Electronic Word of Mouth & 0.771 \\
\hline
\end{tabular}

Based on the table above, it is obvious that the adjusted R-squared (ARC) value of the Brand Equity variable is 0.912 , which is a strong predicate. The electronic word of mouth variable adjusted R-squared (ARC) value of 0.771 has a strong predicate. 


\section{Result and Discussion}

\section{The effect of Social Media Marketing on E-WoM at L'Sima Tourism}

Social media marketing has a positive and significant effect on the electronic word of mouth variable on L'Sima tourism with a path coefficient value of 0.878 . It can be inferred that the more social media marketing is undertaken, the stronger the electronic word of mouth will spread within the community of L'Sima. This is also consistent with the descriptive analysis findings, which show that the highest mean value for the social media marketing variable X1 is "content on Social Media fulfill their needs," and the word of mouth variable X2-1 is "communication through social media is very influential in the spread of information", implying that the effect of social media content in daily needs will affect the flow of information through the social media platforms.

The findings of this study are aligned with (Yan et al., 2016), who examined the effect of social media marketing on E-WoM in social trading. (Afrilina, n.d.)is the second study that connects the variables. The results of this study show that social media marketing has a significant effect on E-WoM. These statements are also in accord with (Živković et al., 2014) that stated when a tourist is making the final decision on destination choice, the most important information comes from online interpersonal influence - online word of mouth (eWOM).

\section{The Effect of Social Media Marketing on Brand Equity on L'Sima Tourism}

According to the findings of Chapter IV analysis, social media marketing has a favorable and significant effect on electronic word of mouth L'Sima's, with a path coefficient value of 0.924 . It can be stated that the more social media marketing performed, the stronger the brand equity for L'Sima.

This is coherent with the descriptive analysis results, which show the highest mean value on the social media marketing is variable $\mathrm{X} 1$, which states, "Content on Social Media can fulfill their needs," and the Y1 brand equity variable, which states, "L'Sima provides a pleasant experience that exceeds the respondent's expectations." Where it is concluded that the effect of good social media content exceeds people's expectations, thus, the value of L'Sima assimilation and educational facility will increase.

In accordance with the present results, previous studies have demonstrated that social media advertisements have significant positive effect on brand equity (Hanaysha, 2016) . (Godey et al., 2016) also found that social media marketing has an effect on brand equity. The third study that connects the variables is (Seo \& Park, 2018), 
the finding in their study stated that the influence of social media on brand equity shows that social media trendiness has a substantial effect on brand awareness and brand image. This result is in accordance with Liwu Hsu et al (2016). According to the research, building brand equity on social media can strengthen the company's image in the minds of consumers while avoiding the negative effects of social media. Another study that supports the results of this research is (Kavisekera \& Abeysekera, 2016)(26), their study found that there is a significant relationship between social media marketing and brand equity of online companies.

\section{The Effect of E-WoM on Brand Equity of L'Sima Tourism}

According to the results in Chapter IV, social media marketing has a positive and significant effect on the electronic word of mouth of L'Sima, with a path coefficient value of 0.454 . It can be concluded that the more intense electronic word of mouth spread, the stronger brand equity L'Sima would obtain.

The result is in line with the findings of descriptive analysis, which show that the electronic word of mouth variable X2-1, which states "communication through social media is very influential in spreading information," and the brand equity variable Y1, which states "L'Sima provides a pleasant experience beyond the respondent's expectations," have the highest mean value. It can be concluded that customer group interaction will generate a pleasant experience for individuals who are interested in sharing information through social media, it who listen to and attend L'Sima.

Therefore, the findings of this study are aligned with (Asdiana \& Yasa, 2020) research, which shows that E-WoM has a significant effect on brand equity. (Bastos \& Moore, 2021) the second study that connects the variables (2021) and stated that EWoM has a significant effect on brand equity. The results are also aligned with Gunawan et al (2019) statement, the findings of their study reveal E-Wom has an important role in the development of an object or tourist destination because it has a significant impact on an image and can be a trigger for revisit intention.

The result is supported by the descriptive analysis, which shows that the social media marketing variable $\mathrm{X} 1$, which states, "Content on social media could fulfill their needs," and the Y1 brand equity variable, which states, "L'Sima gives a pleasant experience exceeding the respondent's expectations," have the highest mean values. So it is determined that the effect of good social media content will exceed people's expectations, and the value of L'Sima will increase. These result is in line with the previous study, according to (Fogel, 2010), the effects of a given advertisement can influence a person to engage in a conversation about a given advertisement, resulting in a strengthening of an object's equity value. 
Indirect Effect of Social Media Marketing on Brand Equity through E-WoM of L'Sima Tourism

The result is supported by descriptive analysis, which demonstrates that the X1 variable has the highest mean value, indicating that "Content on Social Media suits their needs." "L'Sima gives a nice experience that exceeds the respondent's expectations," says variable $\mathrm{Y} 1$, and "communication on social media is particularly influential in the transmission of information," says variable X2-1. People will distribute the knowledge they acquire through the social media they use if social media meets their requirements and provides experiences that exceed their expectations. It can be assumed that the more social media marketing is performed, the stronger the brand equity of L'Sima through electronic word of mouth. However, word of mouth has a stronger effect on the community in transferring information about L'Sima in this study.

This statement is supported by descriptive analysis, which shows that the X1 variable has the highest mean value, implying that "Social Media content meet their needs.", "L'Sima offers a nice experience that exceeds the respondent's expectations," states variable Y1, and "communication on social media is highly influential in the transmission of information," states variable X2-1. People will share the information they acquire through the social media if L'Sima social media contents fulfills their requirements and provides experiences that exceed their expectations.

Therefore, the findings of this study are consistent with (Seo et al., 2020), who stated that the influence of social media marketing on Brand Equity through E-WoM is significant. (Stojanovic et al., 2018) also confirm a positive effect of the intensity of social media use on brand awareness. Results also suggest that brand awareness influences other dimensions of brand equity and highlight the influence of the destination affective image on the intention to make WOM communication. These results are also supporting the previous research conducted by (Keke, 2019) which stated that social media and testimonials have a positive effect on selecting the tourism destination.

\section{Conclusion}

The conclusion of this study concludes that Social Media Marketing, Electronic Word of Mouth on Brand Equity have a significant effect on L'Sima's tourism, both directly and indirectly. Based on the results of descriptive statistical analysis, it can be seen on the result that the descriptive state of social media marketing, brand equity, L'Sima's electronic word of mouth is classified as very good. The second major finding 
is a positive and significant effect between social media marketing on brand equity in L'Sima's tourism. This means if the social media content provided is good, it will increase the value of L'Sima tourism. The research has also shown that there is a positive and significant effect between Social Media Marketing on Electronic Word of Mouth on L'Sima tourism. This means that if social media content fulfills basic necessities, it will have an effect on the electronic word-of-mouth spread about L'Sima tourism to other potential visitors.

This study has also shown there is a positive and significant effect between Electronic Word of Mouth on Brand Equity at L'Sima Assimilation and Education Facilities. This means if the community's habit of interacting is performed out on social media in spreading information, it creates a good experience for the customer, so they would recommend L'Sima through social media to other potential customers. There is a positive and significant effect between Social Media Marketing on Brand Equity through Electronic Word of Mouth at L'Sima Assimilation and Education Facilities. This means that if social media content can fulfill the demand and provide an exceeding experience to the community that distributes information obtained, the value of L'Sima will increase.

Based on the findings, this study recommendations for future research is: (1) the findings of this study can be utilized as a reference to develop other factors that can affect the linked dependent variable. (2) The study object can be studied in order to determine which social media is a recommendation to focus on as the best promotional tool to use. (3) While Instagram, YouTube, and Facebook are the recommended social media platforms, it is likely that other social media platforms can be used to attract more customers than the three specified. (4) The results of this study's discussion show that the value of the Indirect Coefficient is 0.393, implying that there is an influence of 0.393 inferred from social media marketing on brand equity through electronic word of mouth

\section{References}

Afrilina, E. S. (2018). Pengaruh Social Media Marketing Dan Pengetahuan Produk Terhadap Keputusan Pembelian dan Dampaknya Terhadap Electronic Word of Mouth. Jurnal Mahasiswa Manajemen Vol. 7 No. 1 (p. 117-99 ص; •).

Aladwani, A. M. (2017). Compatible quality of social media content: Conceptualization, measurement, and affordances. International Journal of Information Management, 37(6), 576-582. https:/ / doi.org/10.1016/j.ijinfomgt.2017.05.014

Ang, S. H. (2000). Entrepreneurial Spirit among East Asian Chinese. Journal of Enterprising Culture 42(June), 285-309. 
Asdiana, L. D. P., \& Yasa, N. N. K. (2020). The Role of Image Brands Mediates E-Wom Effects on Buying Interest in Triton Learning Institutions. Russian Journal of Agricultural and Socio-Economic Sciences, 103(7), 45-53. https:/ / doi.org/10.18551/rjoas.2020-07.07

Bastos, W., \& Moore, S. G. (2021). Making word-of-mouth impactful: Why consumers React More to WOM about experiential than material purchases. Journal of Business Research, 130(March), 110-123. https:/ / doi.org/10.1016/j.jbusres.2021.03.022

Bui, T.-V. (2014). Social Media On-A-Stick: A Uses And Gratification Approach Toward Helping Mobile Food Vendors Engage Consumers On Instagram The University Of Minnesota.

D. A. Aaker, Managing Brand Equity, Free Press, NY, 1991. [12] P. Barwise, "Brand equity: Snark or boojum?" International Journal of Research in Marketing, vol. 10, no.1, pp. 93-104, 1993.

Dwijananda, I. M., \& Fitria, S. E. (2016). Analisis Pengaruh Electronic Word Mouth Terhadap Proses Keputusan Pembelian (Studi pada Pt. Gojek Di Kota Jakarta, Bandung, Surabaya, Dan Bali). eProceedings of Management, 3(1).

Fogel, S. O. C. (2010). Fogel , S . ( 2010 ). Issues in Measurement of Word of Mouth in Social Media Marketing. International Journal of Integrated Marketing Communications, 2 December 2010, 54-60. https:/ / www.researchgate.net/publication/235612292

Gao, H., Tate, M., Zhang, H., Chen, S., \& Liang, B. (2018). Social Media Ties Strategy In International Branding: An Application Of Resource-Based Theory. Journal of International Marketing, 26(3), 45-69. https:// doi.org/10.1509/jim.17.0014

Godey, B., Manthiou, A., Pederzoli, D., Rokka, J., Aiello, G., Donvito, R., \& Singh, R. (2016). Social media marketing efforts of luxury brands: Influence on brand equity and consumer behavior. Journal of Business Research, 69(12), 5833-5841. https:/ / doi.org/10.1016/j.jbusres.2016.04.181

Gunawan, A. I., Najib, M. F., \& Setiawati, L. (2020, April). The effect of Electronic Word of Mouth (e-WoM) on social media networking. In IOP Conference Series: Materials Science and Engineering (Vol. 830, No. 3, p. 032002). IOP Publishing.

Gururaja, R. (2015). Impact of Social Media on Tourism and Hospitality. Sastech Technical of Journal RUAS, 2(1), 24-26. http:// www.msruas.ac.in/pdf_files/Publications/MCJournals/March2015/4_ Rashmi Gururaj.pdf

Hanaysha, J. (2016). The Importance of Social Media Advertisements in Enhancing Brand Equity: A Study on Fast Food Restaurant Industry in Malaysia. International Journal of Innovation, Management and Technology, 7(2), 46-51. https:/ / doi.org/10.18178/ijimt.2016.7.2.643

Huang, C. C., Yen, S. W., Liu, C. Y., \& Chang, T. P. (2014). The Relationship Among Brand Equity, Customer Satisfaction, And Brand Resonance To Repurchase 
Intention Of Cultural And Creative Industries In Taiwan. International Journal of Organizational Innovation (Online), 6(3), 106.

Jalilvand, M. R., \& Samiei, N. (2012). The effect of electronic word of mouth on brand image and purchase intention: An empirical study in the automobile industry in Iran. Marketing Intelligence and Planning, 30(4), 460-476. https:/ / doi.org/10.1108/02634501211231946

Jayani, D. (2021, May 24). Proporsi Populasi Generasi Z dan Milenial Terbesar di Indonesia. https://databoks.katadata.co.id/datapublish/2021/05/24/proporsipopulasi-generasi-z-dan-milenial-terbesar-di-indonesia.

Jeong, E., \& Jang, S. S. (2011). Restaurant experiences triggering positive electronic word-of-mouth (eWOM) motivations. International Journal of Hospitality Management, 30(2), 356-366.

Kaur, G. (2017). the Importance of Digital Marketing in the Tourism Industry. International Journal of Research -GRANTHAALAYAH, 5(6), 72-77. https:/ / doi.org/10.29121/granthaalayah.v5.i6.2017.1998

Kavisekera, S., \& Abeysekera, N. (2016). Effect of Social Media Marketing on Brand Equity of Online Companies. Management E Marketing, 14(2), 201-2016.

Keke, Y. (2019). The Impact of Social Media and Testimony on Selecting the Tourism Destination. 343(Icas), 511-516. https:/ / doi.org/10.2991/icas-19.2019.105

Kim, A. J., \& Ko, E. (2012). Do Social Media Marketing Activities Enhance Customer Equity? An Empirical Study of Luxury Fashion Brand. Journal of Business Research, 65(10), 1480-1486. https://doi.org/10.1016/j.jbusres.2011.10.014

Kim, B., Yoo, M. M., \& Yang, W. (2019). Online engagement among restaurant customers: The importance of enhancing flow for social media users. Journal of $\begin{array}{lllll}\text { Hospitality } \mathcal{E} \text { Tourism } & \text { 252-277. }\end{array}$ https:/ / doi.org/10.1177/1096348019887202

Kotler, P., \& Keller, K. L. (2009). Manajemen Pemasaran, Edisi 13. Jakarta: Erlangga, 14. Laksana, Daniel \& Dharmayanti, D. (2018). Pengaruh Digital Marketing Terhadap Organizational Performance Dengan Intellectual Capital Dan Perceived Quality Sebagai Variabel InterveniDharmayanti, L. \&. (2018). Pengaruh Digital Marketing Terhadap Organizational Performance Dengan Intellectual Capita. Jurnal Manajemen Pemasaran, 12(1), 10-24. https:// doi.org/10.9744/ pemasaran.12.1.10

Lee, K.-T., \& Koo, D.-M. (2012). Effects Of Attribute And Valence Of E-WOM On Message Adoption: Moderating Roles Of Subjective Knowledge And Regulatory Focus. Computers in human behavior, 28(5), 1974-1984. https:// doi.org/10.1016/j.chb.2012.05.018

Leone, N., Courbon, D., Thomas, F., Bean, K., Jégo, B., Leynaert, B., Guize, L., \& Zureik, M. (2009). Lung function impairment and metabolic syndrome the critical role of abdominal obesity. American Journal of Respiratory and Critical Care Medicine, 179(6), 509-516. https:/ / doi.org/10.1164/rccm.200807-1195OC

Ly, B., \& Ly, R. (2020). Effect of Social Media in Tourism (Case in Cambodia). J Tourism 
Hospit, 9(1), 424. https:/ / doi.org/10.35248/2167-0269.20.9.424

Nurhayati, H. (2021, August 16). Number Of Internet Users In Indonesia 2017-2026. Statista. Https://Www.Statista.Com/Statistics/254456/Number-Of-InternetUsers-In-Indonesia/

Putri, N., Rachmawati, I., Sidiq, F., Prabowo, A., Prodi, S., Bisnis, M., \& Ekonomi, F. (2016). Pengaruh Electronic Word Of Mouth Terhadap Brand Equity Indomie (Studi Pada Followers Official Account Jejaring Sosial Indomie). 3(3), 2976-2984.

Rossmann, A., Ranjan, K. R., \& Sugathan, P. (2016). Drivers Of User Engagement In EWOM Communication. Journal of Services Marketing, 30(5), 541-553. https:/ / doi.org/10.1108/JSM-01-2015- 0013

Santoso, R. (2020). Review of Digital Marketing \& Business Sustainability of ECommerce During Pandemic Covid19 In Indonesia. Jurnal Ilmu Ekonomi Terapan, $5(2), 36-48$.

Seo, E. J., \& Park, J. W. (2018). A Study On The Effects Of Social Media Marketing Activities On Brand Equity And Customer Response In The Airline Industry. Journal of Air Transport Management, 66(September 2017), 36-41. https:/ / doi.org/10.1016/j.jairtraman.2017.09.014

Sindunata, I. (2018). Pengaruh Electronic Word of Mouth terhadap Keputusan Pembelian di agoda.com. Hospitality Dan Manajemen Jasa, 6(1), 128-138.

Severi, E., \& Ling, K. C. (2013). The Mediating Effects Of Brand Association, Brand Loyalty, Brand Image And Perceived Quality On Brand Equity. Asian Social Science, 9(3), 125.

Stojanovic, I., Andreu, L., \& Curras-Perez, R. (2018). Effects Of The Intensity Of Use Of Social Media On Brand Equity: An Empirical Study In A Tourist Destination. European Journal of Management and Business Economics, 27(1), 83-100. https:/ / doi.org/10.1108/EJMBE-11-2017-0049

Tekin, G. (2016). The Effect of Brand Image on Consumer Behaviour: Case Study of Louiss Vuitton-Mo. International Journal of Academic Value Studies (Javstudies JAVS), 2(2), 1-24. https:/ / doi.org/10.23929/javs.47

W. J. Keegan, S. Moriarty, and T. Duncan, Marketing, Prentice Hall: Englewood Cliffs, 1995.

Yan, Q., Wu, S., Wang, L., Wu, P., Chen, H., \& Wei, G. (2016). E-WOM From ECommerce Websites And Social Media: Which Will Consumers Adopt? Electronic Commerce Research and Applications, 17, 62-73. https:/ / doi.org/10.1016/j.elerap.2016.03.004

Yasin, M.N. dan Zahari, R.A. (2011). Does Family And Viral Marketing Have Any Effect On Brand Equity? Contemporary Marketing Review, Vol. 1(8), pp.01 13.

Živković, R., Gajić, J., \& Brdar, I. (2014). The Impact of Social Media on Tourism. 758-761. https:/ / doi.org/10.15308/sinteza-2014-758-761 